\title{
Pelatihan Budidaya Maggot Black Soldier Fly sebagai Pakan Alternatif dalam Upaya Pengolahan Sampah Organik Rumah Tangga
}

\author{
Resti Rahayu $^{1}$, Eli Ratni ${ }^{2}$, Henny Herwina ${ }^{1}$, Robby Jannatan ${ }^{1}$, Virtuous Setyaka ${ }^{3}$, dan Wellyalina ${ }^{4}$ \\ ${ }^{1}$ Fakultas Matematika dan Ilmu Pengetahuan Alam, Universitas Andalas, Kampus Limau Manis, Padang, 25163. Indonesia \\ ${ }^{2}$ Fakultas Peternakan, Universitas Andalas, Kampus Limau Manis, Padang, 25163. Indonesia \\ ${ }^{3}$ Fakultas Ilmu Sosial dan Ilmu Politik, Universitas Andalas, Kampus Limau Manis, Padang, 25163. Indonesia \\ ${ }^{4}$ Fakultas Teknologi Pertanian, Universitas Andalas, Kampus Limau Manis, Padang, 25163. Indonesia \\ e-mail: restirahayu@sci.unand.ac.id
}

Keywords:

black soldier fly, feed alternative, maggot larvae organic waste

Kata Kunci: lalat tentara hitam, maggot, pakan alternatif, sampah organik

\section{ABSTRACT}

The city of Padang produces approximately 600 tons of waste daily, which includes the categories of recyclable and non-recyclable waste. However, the percentage of waste that can be recycled is only about $17 \%$ and the rest must be heaped into end landfill every day. The category of recycled waste is counted as much as $65 \%$ is organic waste that is made into compost and $35 \%$ is both plastic and paper waste that is processed into other products. Maggot, which is the larva of the Black Soldier Fly, is an organic matter-decomposing agent that has better decomposition capabilities than other organisms. Maggot has biomass with high protein and fat content. Maggot farming is the most appropriate effort needed by the community today, because in addition to processing daily organic waste, it will also produce feed for livestock such as chicken, duck, fish, and bird. The farming process only requires simple technology and low cost, but is able to reduce the earth's waste load. The Andalas University community service team provided training on maggot farming to process organic waste from community households. The training was carried out using the Hybrid method, which is a combination of offline and online techniques with the same goal. The activity began with counseling on theoretical explanations, followed by both the farming practices and further program assisting. It hopes that the activity will be improved by other trainings such as Maggot's processing into more valuable products, so that it can be packaged in such a way as to be marketed to the target purchasers.

\section{ABSTRAK}

Kota Padang dibebani oleh produksi kurang lebih 600 ton sampah harian, yang mencakup kategori sampah yang bisa didaur ulang dan tidak bisa. Namun, persentase sampah yang bisa didaur ulang hanya sekitar $17 \%$ dan sisanya harus ditimbun ke tempat pembuangan sampah akhir setiap hari. Kategori sampah daur ulang terhitung sebanyak 65\% merupakan sampah organik yang dijadikan kompos dan 35\% merupakan sampah plastik dan kertas yang diolah menjadi produk lain. Maggot, yang merupakan larva dari Lalat Tentara Hitam (Black Soldier Fly), adalah agen pengurai materi organik yang memiliki kemampuan mengurai lebih baik dibandingkan dengan organisme lainnya. Maggot memiliki biomassa dengan kandungan protein dan lemak tinggi. Budidaya maggot merupakan upaya paling tepat yang dibutuhkan oleh masyarakat saat ini, karena disamping mengolah sampah organik juga akan menghasilkan bahan makanan untuk ternak seperti ayam, 
itik, ikan, dan burung. Proses pembudidayaan hanya membutuhkan teknologi sederhana dan biaya murah, namun mampu mengurangi beban sampah bumi. Tim pengabdian masyarakat Universitas Andalas memberikan pelatihan budidaya maggot untuk mengolah sampah organik yang berasal dari rumah tangga masyarakat. Pelatihan dilakukan dengan metode Hybrid, yakni perpaduan teknik secara luring dan daring dengan tujuan yang sama. Kegiatan diawali dengan penyuluhan tentang penjelasan teori, diikuti dengan praktek budidaya, serta pendampingan lanjutan. Saran untuk kegiatan ini yakni pengadaan penyuluhan dan pendampingan untuk mengolah Maggot menjadi produk turunan, sehingga bisa dikemas sedemikian rupa untuk dipasarkan ke target sasaran yang membutuhkan.

\section{PENDAHULUAN}

Lalat tentara hitam atau biasa dikenal dengan Black Soldier Fly (BSF) atau dalam bahasa latin bernama Hermetia illucens merupakan salah satu jenis lalat yang mempunyai banyak manfaat bagi manusia. Lalat ini bukanlah vektor penyakit seperti jenis lalat lainnya yang hinggap di tempat kotor dan membawa kuman ke makanan manusia. Maggot atau larva dari BSF ini mempunyai banyak manfaat seperti untuk makan ayam, makan ikan, subtitusi protein pakan, makan burung dan lain-lain. Maggot menjadi protein alternatif untuk makanan ternak, oleh sebab itu budidaya maggot untuk berbagai keperluan akan mengefisiensikan produksi pakan bagi para peternak.

Maggot adalah agen pengurai materi organik yang memiliki kemampuan mengurai lebih baik dibandingkan dengan organisme lainnya. Maggot memiliki biomassa dengan kandungan protein dan lemak tinggi. Hasil analisa proksimat maggot mengandung protein 43,42\%, lemak 17,24\%, serat kasar 18,82\%, abu 8,70\% dan air 10,79\% (Laboratorium Teknologi Hasil Perikanan, FPIK-Undip, 2011) dalam Rachmawati dkk. (2013). Hasil penelitian Indariyanti dan Barades (2018) memperoleh kandungan protein maggot sebesar 44,58 \%, asam lemak linolenat 1,98\%, dan linoleat 3,67\%.

Montesqrit dkk. (2020) sudah melakukan penelitian tentang pemberian tepung maggot BSF yang optimal adalah 6\% dalam ransum ayam pedaging dimana mampu meningkatkan konsumsi ransum dan penambahan bobot badan lebih tinggi yakni masing masing 713,31 g/ekor/minggu dan 379,70 g/ekor/minggu dan konversi ransum lebih rendah yaitu sebesar 1,88. Lebih lanjut, memelihara maggot dan menjadikannya sebagai pakan alternatif akan berdampak pada biaya produksi menjadi jauh lebih murah, masalah sampah pun akan teratasi, karena makanan maggot adalah sampah (Rahayu dkk., 2020).

Disamping itu, jika kita membaca data tentang sampah di kota Padang, tercatat 600 ton sampah yang diproduksi oleh masyarakat setiap hari. Dari angka tersebut, baru 100 ton yang bisa dikelola menjadi kompos atau didaur ulang, dan sisanya seberat 500 ton sampah tetap harus ditimbun di TPA Air Dingin. Dari 100 ton sampah yang diolah, 65\% merupakan sampah organik yang bisa dijadikan kompos dan 35\% merupakan sampah plastik dan kertas yang bisa didaur ulang (www.dlh.padang.go.id).

Koperasi Pemasaran Mandiri dan Merdeka (KMDM) didirikan pada tanggal 20 Januari 2020 oleh sekelompok penggagas yang peduli dengan petani, peternak, nelayan, dan produsen pangan skala kecil. KMDM membentuk sebuah unit bank sampah yakni Bank Sampah \& Ecoenzyme (BaSE), beralamat di Jl. Cupak Tangah No.29, Cupak Tangah, Kec. Pauh, Kota Padang, Sumatera Barat 25158. Unit ini memiliki tugas khusus untuk proses edukasi pengolahan sampah di masyarakat. Anggota dan nasabah BaSE terus berupaya untuk mengurangi beban sampah kota Padang melalui penguraian sampah organik dan pengolahan kembali sampah non organik. BaSE mengakomodir permintaan 
anggota atau nasabahnya tentang pengolahan sampah organik yang berasal dari rumah tangga atau lingkungan terdekat menjadi produk bernilai.

Budidaya maggot merupakan upaya paling tepat yang dibutuhkan oleh masyarakat, disamping mengolah sampah organik juga akan menghasilkan bahan makanan untuk ternak seperti ayam, itik, ikan, dan burung. Kegiatan pengabdian masyarakat dengan topik "Teori dan Praktek Budidaya Maggot Black Soldier Fly dalam Pengolahan Sampah Organik Rumah Tangga" dilaksanakan berdasarkan kerjasama antara BaSE KMDM dan dosen Universitas Andalas.

\section{METODE}

Pelaksanaan pengabdian masyarakat ini didisain dengan teknik Hybrid, yakni perpaduan penyuluhan yang dilangsungkan secara luring dan daring dengan tujuan yang sama. Mitra masyarakat dalam kegiatan ini adalah hasil kerjasama antara tim dosen pengabdi dengan Bank Sampah \& Ecoenzyme Koperasi Pemasaran Mandiri dan Merdeka (BaSE KMDM). Kegiatan terdiri dari empat tahapan, yaitu persiapan, pelaksanaan (penyuluhan dan pendampingan), dan evaluasi.

Pada tahap persiapan, masyarakat yang tergabung dalam komunitas BaSE KMDM, termasuk pengelola dan nasabahnya, membutuhkan upaya untuk mengolah sampah organik yang menghasilkan produk organik juga. Metode yang paling tepat adalah praktek membudidayakan maggot dengan pemberian makanan utamanya adalah sampah di setiap rumah tangga. Selanjutnya dibentuk Tim Dosen untuk Pengabdian kepada Masyarakat dari Universitas Andalas. Komunikasi dua arah terbentuk antara tim Dosen dan BaSE KMDM yang menyepakati sebuah program berkelanjutan untuk mengolah sampah dan memproduksi maggot. Pada tahap pelaksanaan, tim pengabdi memberikan penyuluhan tentang Budidaya Maggot secara teori dan praktek di Rumah Magot. Kegiatan ditindaklanjuti dengan cara mendampingi masyarakat untuk memproduksi larva BSF di lapangan. Tahap evaluasi adalah tahapan dimana tim dosen pengabdi bersama semua orang yang terlibat dalam program pengabdian masyarakat ini mendiskusikan sekaligus merefleksikan mengenai efektifitas dan efisiensi pelaksanaan program pengabdian kepada masyarakat ini.

\section{HASIL DAN PEMBAHASAN}

Pengabdian kepada masyarakat yakni "Teori dan Praktek Budidaya Maggot Black Soldier Fly dalam Pengolahan Sampah Organik Rumah Tangga" ini sudah diselenggarakan pada tanggal 6, 7, dan 20 Maret 2021, dengan metode Hybrid antara luring dan daring. Materi penyuluhan disampaikan langsung oleh tutor Dr. Resti Rahayu di Rumah Magot Komplek Bukit Belimbing Indah Blok A5 Kota Padang, pada tanggal 6 Maret 2021. Presentasi dimulai dari penjelasan siklus hidup Black Soldier Fly (BSF) dan terbentuknya Maggot secara teori, manfaat Maggot untuk pakan ternak seperti unggas dan ikan, bahkan sebagai bahan baku kosmetik, dan jenis sampah yang bisa digunakan untuk makanan Maggot itu sendiri. BSF atau hermetia illucens (latin) atau Lalat Tentara Hitam (Indonesia) adalah salah satu jenis lalat di dunia yang memiliki banyak kelebihan dan manfaat bagi manusia. BSF adalah jenis lalat yang bukan merupakan vektor penyakit seperti lalat hijau atau lalat sampah, yang hinggap dan makan pada tumpukan sampah, tapi jenis lalat yang bersih.

Para peserta pelatihan tersebut terdiri dari para Pengurus BaSE KMDM yang dimaksudkan untuk membangun kapasitas mereka untuk mampu memahami, mempraktekkan, dan melatih masyarakat umum dalam budidaya maggot BSF. Selain itu, 
pesertanya juga masyarakat umum khususnya para produsen (petani, peternak, dan pelaku usaha mikro kecil dan menengah) dan konsumen (yang biasa berbelanja di) Pasar Rabu Tani (PRT) KMDM yang dibatasi hanya 15 sampai 20 orang dengan protokol kesehatan seketat mungkin terkait pandemi Covid-19. Selama pelatihan, baik para narasumber dan peserta diwajibkan untuk memakai masker, menjaga jarak, dan mencuci tangan dengan sabun, dan seterusnya.

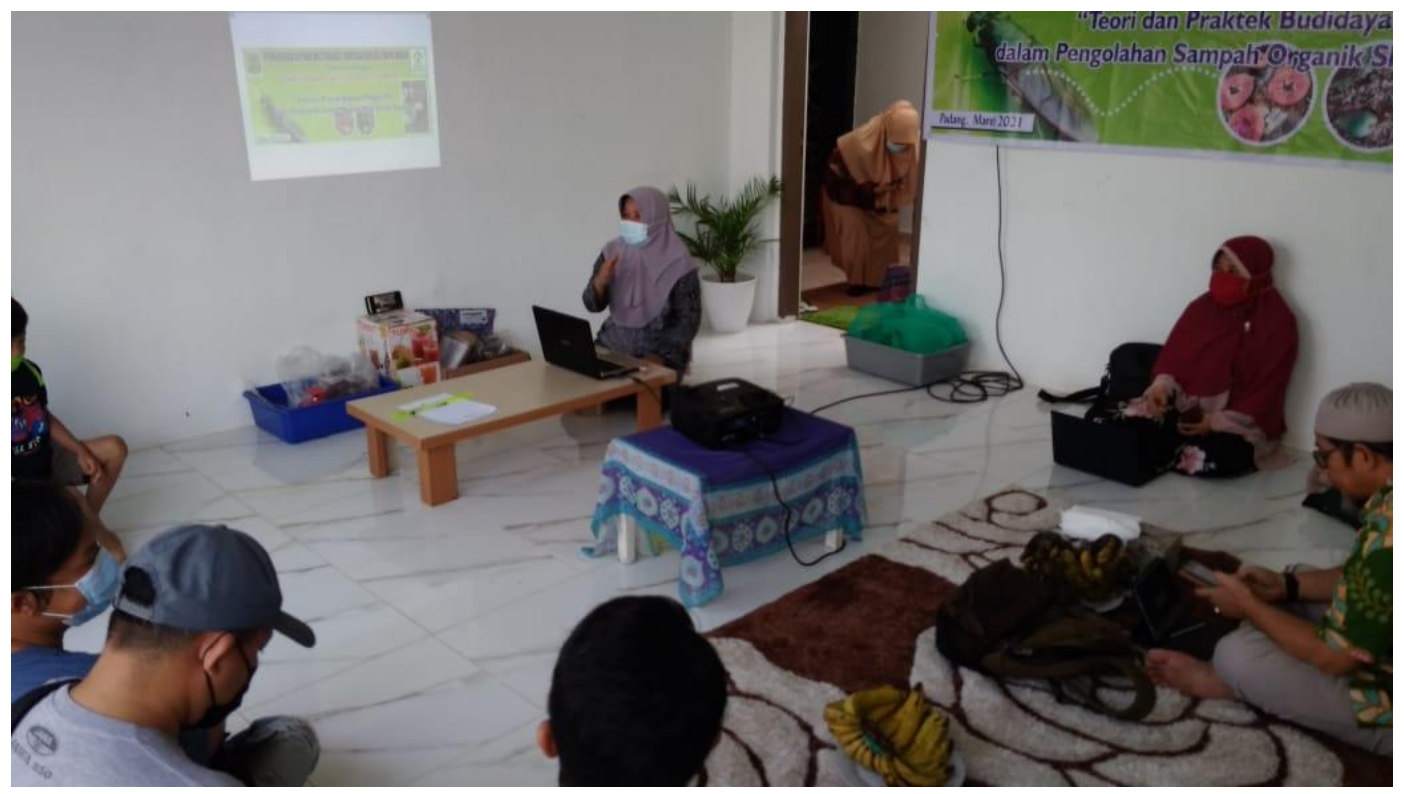

Gambar 1. Penyampaian materi tentang budidaya Maggot BSF oleh Dr. Resti Rahayu

Setelah sesi presentasi berlangsung, peserta pengabdian diajak oleh pemilik Rumah Magot untuk mengenali dan mengamati kehidupan BSF di kandangnya, proses bertelur dan penetasan, proses pemindahan telur ke wadah budidaya menjadi larva, dan proses pertumbuhan larva menjadi maggot dengan hanya memakan sampah organik. Dr. Resti Rahayu mengatakan bahwa magot adalah solusi untuk protein alternatif bagi ternak baik itu diberikan secara langsung atau dijadikan subtitusi protein pakan. Maggot menjadi solusi penanganan sampah organik di perkotaan, karena dalam beberapa gram maggot saja bisa menghabiskan berkilo-kilo sampah organik. Budidayanya juga tergolong murah dan mudah untuk dilakukan oleh siapa saja.
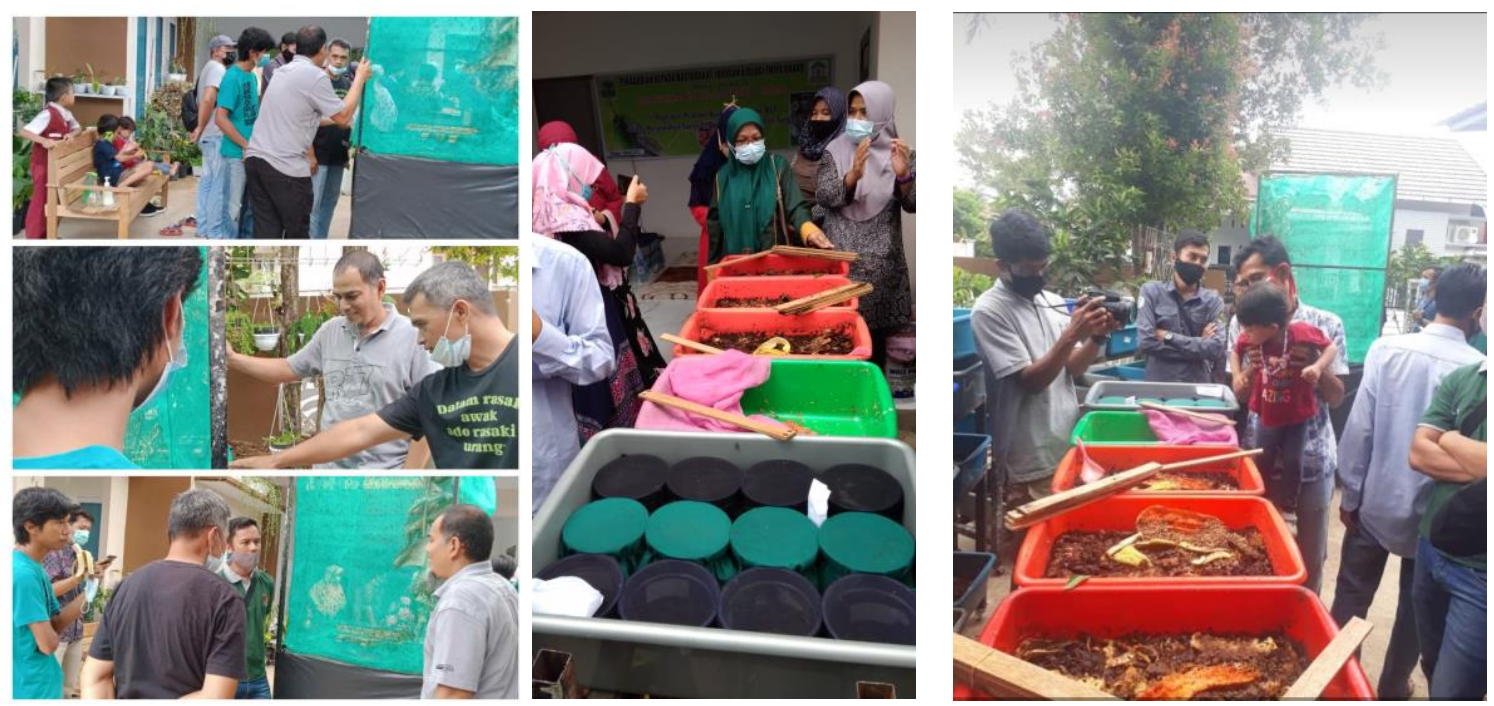

Gambar 2. Pengamatan praktek budidaya Maggot di Rumah Maggot 
Sesi terakhir di hari pertama ditutup dengan penjelasan status Ke-Halal-an maggot oleh Dr. Syaifullah, disamping sebagai Dosen Biologi FMIPA Unand, beliau juga salah seorang Auditor Halal LPPOM MUI. Menurut Dr. Syaifullah bahwa maggot dikategorikan dalam hewan yang menjijikkan sehingga Tidak Halal jika menjadi makanan manusia. Namun, daging ternak yang diberikan maggot sebagai pakannya, baik dalam bentuk utuh maupun berbentuk tepung maggot, adalah Halal untuk dikonsumsi oleh manusia, dengan memenuhi syarat Halal juga dalam hal pemotongan.

Berhubung keterbatasan lokasi dan untuk mematuhi protokol kesehatan akibat pandemi Covid-19, ada sebagian peserta terdaftar yang tidak bisa diikutkan pada kegiatan pertama, sehingga harus diadakan penyuluhan dan pendampingan tahap ke-2 oleh BaSE KMDM. Metode yang digunakan juga sama, penggabungan komunikasi antara offline dan online. Disamping itu, kegiatan pelatihan juga diberitakan pada beberapa media massa online di kota Padang, seperti Beritasumbar.com, Harianhaluan.com, Suararantau.com, Piramida.id, Siarminang.net, dan laman internet Jurusan Biologi FMIPA Unand, dengan tujuan untuk menyasar lebih banyak masayarakat yang bisa terlatih dari kegiatan ini.

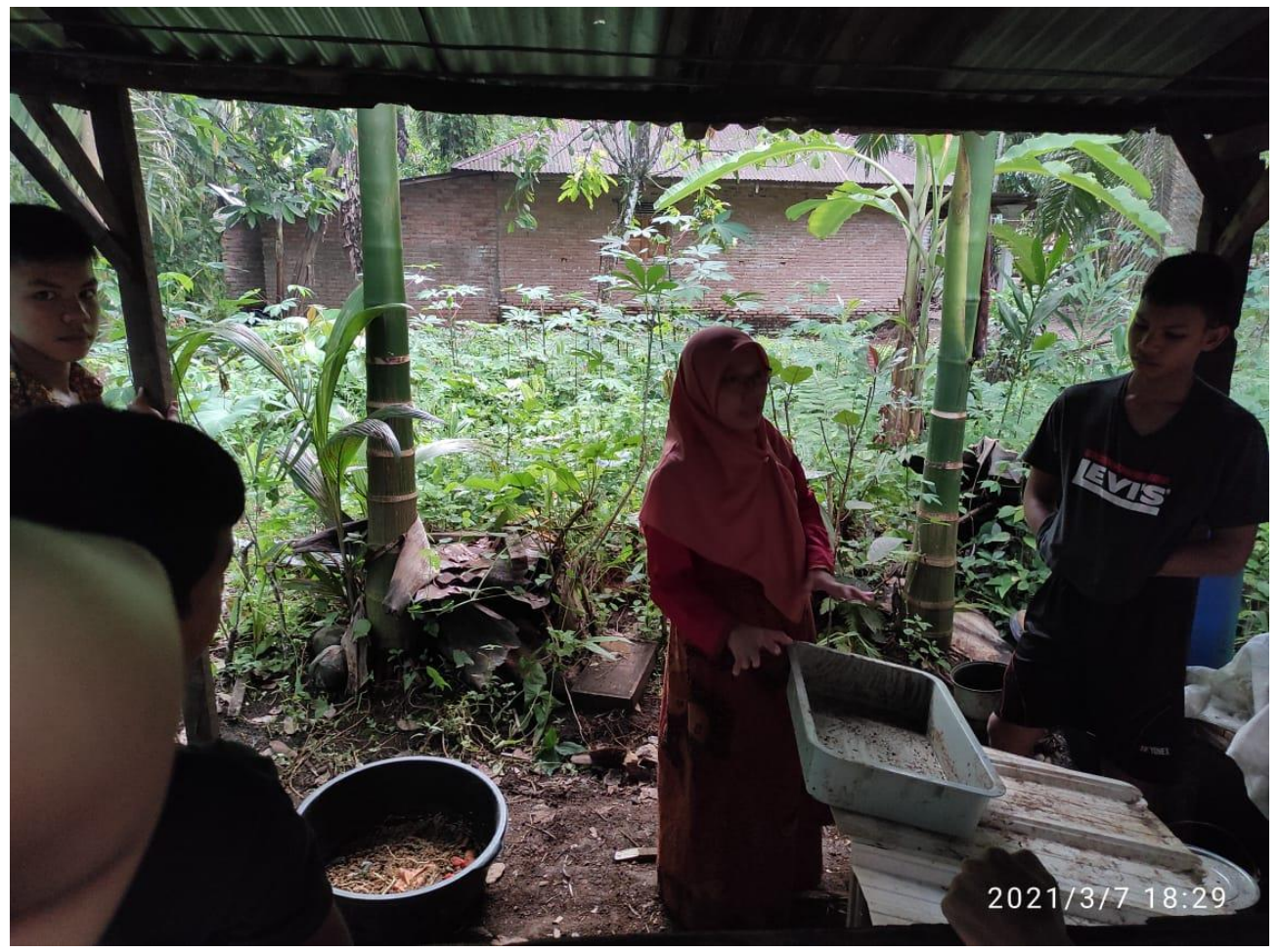

Gambar 3. Pendampingan budidaya Maggot BSF di lokasi koloni peternak

Tahap evaluasi Proses ini berlangsung secara daring sebagai upaya tindak lanjut proses penyuluhan dan pendampingan kegiatan, maka tim pengabdi menyediakan wadah komunikasi berbentuk grup WhatsApp (WAG). Peserta kegiatan sangat antusias mengikuti kegiatan ini. Harapannya dari terselenggaranya kegiatan ini bisa memotivasi masyarakat untuk mengolah sampah organik rumah tangga dan mendapatkan hasil secara ekonomi dari produksi larva maggot melalui jaringan yang terintegrasi bersama koperasi dan perguruan tinggi. 


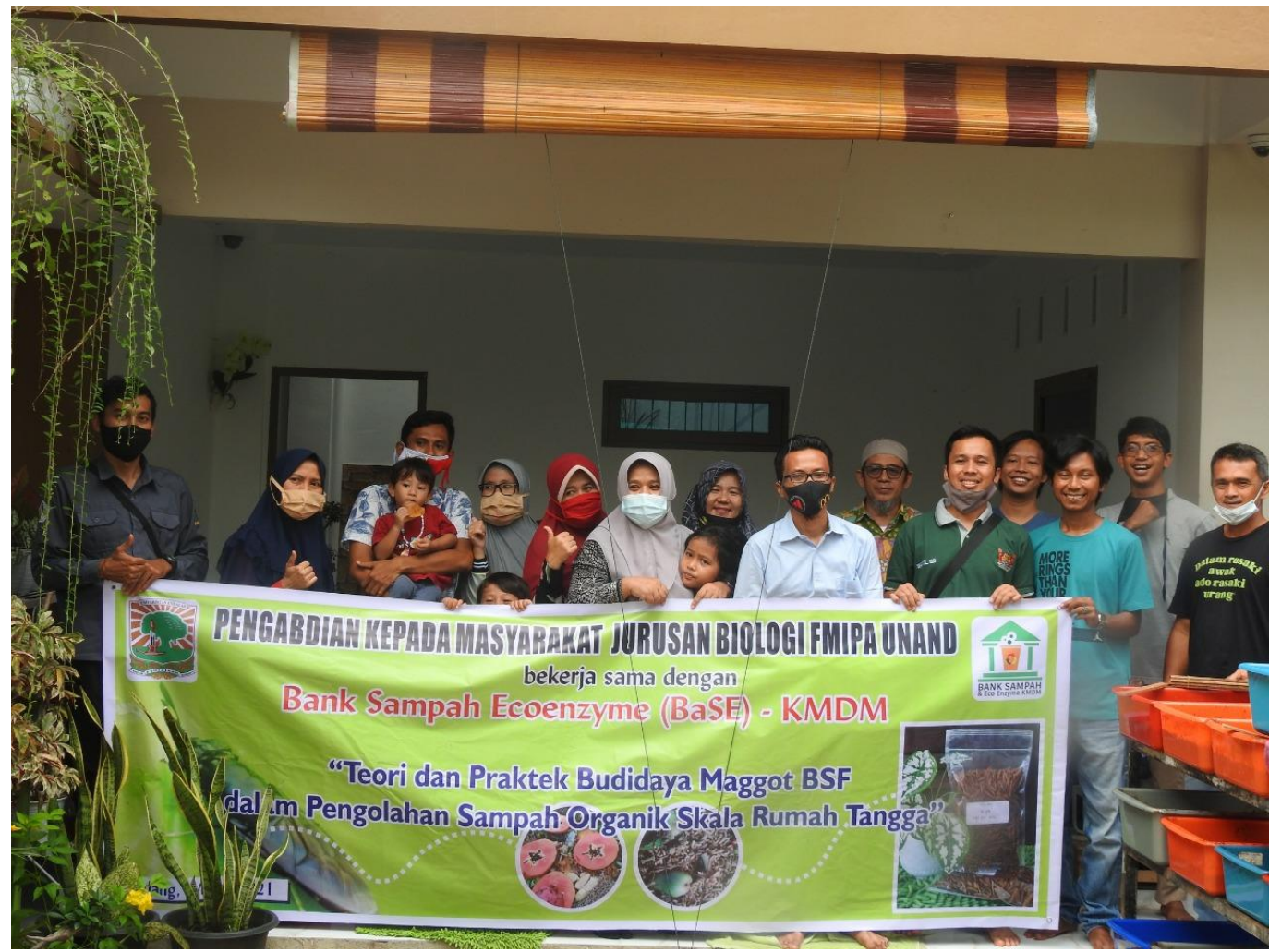

Gambar 4. Sebagian peserta kegiatan budidaya Maggot BSF

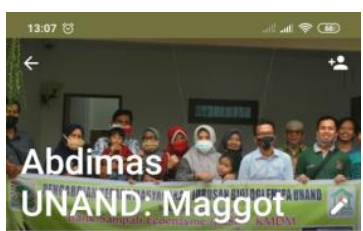

Description

Sebagai upaya tindak lanjut dari program Pengabdian kepada Masyarakat dengan topik "Teori dan Praktek tentang Budidaya Maggot BSF dalam Pengolahan Sampa Organik Skala Rumah Tangga" denga Tutor lbu Dr. Resti Rahayu (Biologi (N) dan Ecoenzyme Koperasi Pemasara

Maka Kami menyediakan grup WA sebagai wadah komunikasi lanjutan dalam hal budidaya Maggot dan pemanfaatannya di

Semoga bermanfaat:

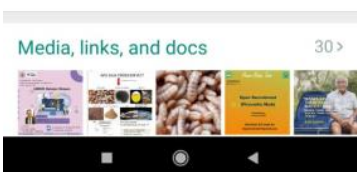

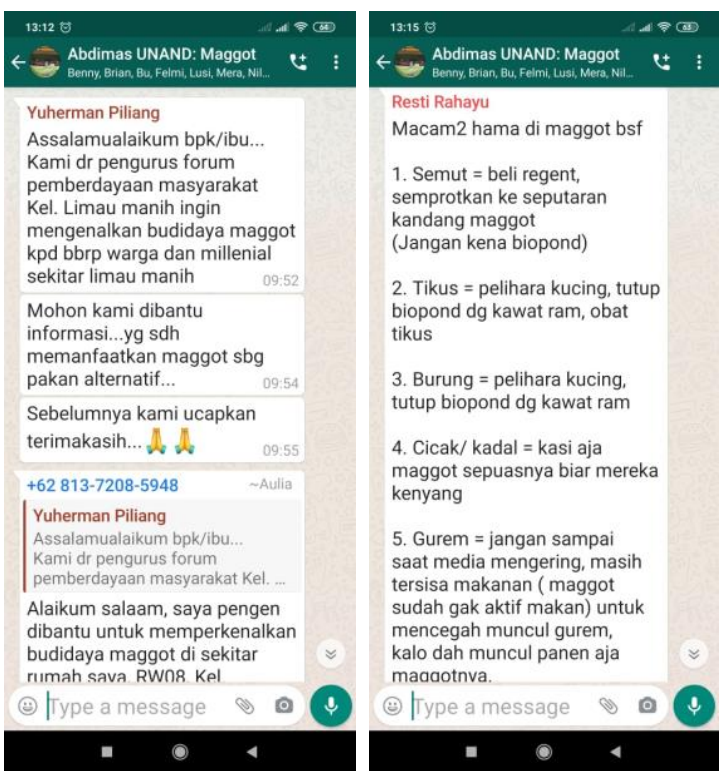

Gambar 5. Cuplikan komunikasi daring sebagai upaya tindak lanjut dan evaluasi kegiatan 


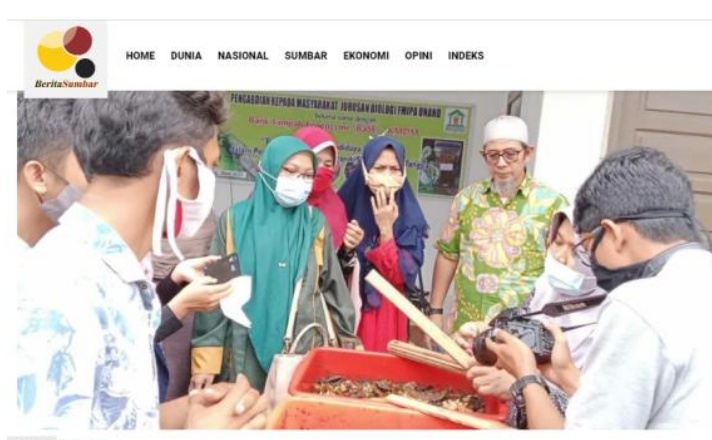

Tim PKM Biologi Unand dan BaSE KMDM Gelar Kerja Sama Pelatihan Budidaya Maggot BSF

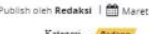

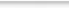

\section{$\bullet 00 \bullet \bullet$}

Gambar 6. Pemberitaan kegiatan pelatihan di media massa online

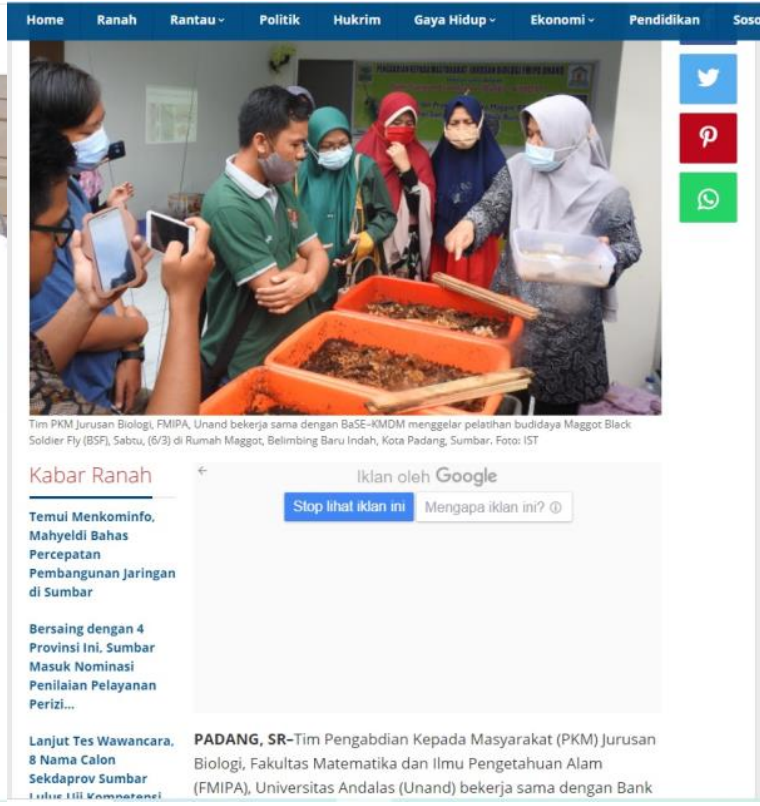

\section{KESIMPULAN}

Kegiatan pengabdian kepada masyarakat ini disambut baik oleh masyarakat, yakni anggota KMDM, pengelola dan nasabah BaSE KMDM, dan petani serta peternak. Penjelasan tentang keharusan mengolah sampah rumah tangga sendiri dan banyaknya manfaat dari Maggot harus dikemas menjadi sebuah bentuk Edukasi. Praktek budidaya Maggot BSF sangat mudah untuk dilakukan oleh siapa pun. Proses pembudidayaan hanya membutuhkan teknologi sederhana dan biaya murah, namun mampu mengurangi beban sampah bumi. Maggot sebagai produk yang diharapkan bisa dimanfaatkan sebagai bahan pakan ternak alternatif di tengah melambungnya harga pakan konvensional, terutama untuk komoditi unggas. Saran untuk kegiatan ini yakni pengadaan penyuluhan dan pendampingan untuk mengolah Maggot menjadi produk turunan, sehingga bisa dikemas sedemikian rupa untuk dipasarkan ke target sasaran yang membutuhkan.

\section{UCAPAN TERIMA KASIH}

Terima kasih disampaikan kepada Lembaga Penelitian dan Pengabdian (LPPM) Unand dan Jurusan Biologi FMIPA Unand. Terima kasih juga kepada segenap pengurus dan anggota Koperasi Pemasaran Mandiri dan Merdeka dengan unit bisnis Bank Sampah \& Ecoenzyme (BaSE).

\section{DAFTAR PUSTAKA}

Indariyanti, N. dan E. Barades. 2018. Evaluasi Biomassa dan Kandungan Nutrisi Magot (Hermetia illucens) pada Media Budidaya yang Berbeda. Prosiding Seminar Nasional PengembanganTeknologi Pertanian. Politeknik Negeri Lampung. Hal. 137-141.

Montesqrit, M., Harnentis, H. dan Rahmat, R. 2020. Optimasi Pemberian Tepung Maggot dari Larva Black Soldier Fly (Hermetia Illucens) dalam Ransum Ayam Pedaging. 
Prosiding Seminar Teknologi Agribisnis Peternakan (STAP) Fakultas Peternakan Universitas Jenderal Soedirman, 7, p. 556. Available at: http://jnp.fapet.unsoed.ac.id/index.php/psv/article/view/495.

Rachmawati, D. dan Samidjan, I. 2013. Efektivitas substitusi tepung ikan dengan tepung maggot dalam pakan buatan terhadap pertumbuhan dan kehidupan ikan patin (Pangasius pangasius). Jurnal Saintek Perikanan. 9 (1): 62-67.

Rahayu, R., H. Rahma, dan Zulkarnain. 2020. Unand perkenalkan "maggot" sebagai pakan alternatif untuk ikan dan unggas. http://www.indomen.co.id/2020/12/unand-perkenalkan-maggot-sebagaipakan.html

www.dlh.padang.go.id/category/berita.

https://dlh.padang.go.id/menguraipermasalahan -sampah-di-kota-padang 